\title{
In vitro multiplication and cultivation of Actinidia arguta in the Republic of Moldova
}

\section{Tatiana Calugaru-Spataru, \\ Raisa Ivanova ${ }^{*}$,}

\section{Alexandru Dascaliuc}

The Center of Advanced

Biological Technologies,

Institute of Genetics \&

Plant Physiology,

Academy of Science of Moldova,

20 Padurii Str.,

Chisinau MD-2002,

Republic of Moldova
Actinidia arguta is a perennial fruit vine, not characteristic for natural flora of Moldova. This species is of interest to gardeners due to its high ornamental value, as well as exotic fruits (hardy kiwifruits). The research of this species has been carried out at the Experimental station of the Institute of Genetics and Plant Physiology of the Academy of Science of Moldova throughout in the period of eight years. Particular attention was paid to optimization of the methods of vegetative propagation and conditions of cultivation of a perspective and highly productive clone named Tatiana, previously selected from the generative propagated plants. The apical meristems of adult plants served as source for elaborating the method of in vitro micropropagation. As a result of testing different nutrients, the cultural medium for in vitro propagation (with the multiplication factor equal to seven) and organogenesis was elaborated. Plants adaptation to ex vitro conditions was assured by gradually increasing the light intensity, reducing the relative humidity from $95 \%$ to that of natural. In conditions of Central Moldova the crop yield from one 5-7-year plant of Tatiana clone was varying between 2 and $10 \mathrm{~kg}$. The hardy kiwifruits were characterized by valuable organoleptic and biological properties. The antioxidant activity of kiwifruits juice determined by the potentiometric method and expressed in equivalent of vitamin C (VCEAC) was equal to $9.26 \pm 0.28 \mu \mathrm{Mol} / \mathrm{g}$ (per dry residue). Due to high content of phenols in hardy kiwifruits of Tatiana clone that remains stable during storage they can become a valuable source of nutrient substances.

Key words: Actinidia arguta, in vitro micropropagation, hardy kiwifruits, antioxidant activity, phenolics

\section{INTRODUCTION}

The relict plant of Actinidia arguta is a woody vine that in natural conditions grows on stony

\footnotetext{
* Corresponding author. E-mail: ralivanova@yahoo.com
}

soils in southern Siberia, Manchuria, northern China, Korea and Japan (Zuo et al., 2012). The climbing vines of Actinidia arguta can reach up to $25 \mathrm{~m}$ in length and $15-18 \mathrm{~cm}$ in thickness. This fact gives the possibilities to use these plants for ornamental decoration of gardens. 
The fast-growing, climbing vine is very hardy and capable of surviving gradual temperature drops up to $-34{ }^{\circ} \mathrm{C}$, although young shoots can be vulnerable to frost in the spring. Late spring frost is very common in Moldova and other European countries (Marosz, 2009). The attention of many European scientists goes towards Actinidia arguta because of the possibilities to cultivate it as edible fruits (hardy kiwifruits). Searching for new plants that can be grown commercially and that are valuable for human health is an important task for horticultural science. Actually, in the international market Actinidia fruit sales are dominated by a single kiwifruit cultivar Actinidia deliciosa "Hayward". There are a considerable number of cultivars and selections in the genus that have a widely diverse shape, size, and hairiness (Nishiyama et al., 2004). In fruits of Actinidia arguta and their interspecies hybrids, the contents of chlorophyll, lutein, and beta-carotene were much higher than in "Hayward". In particular, these fruits were found to be the richest dietary source of lutein among commonly consumed fruits (Nishiyama et al., 2005). Recent studies have found the medicinal efficacy such as antioxidant activity of kiwifruit extracts (Zuo et al., 2012; Motohashi et al., 2001; Scalzo et al., 2005; Ivanova et al., 2010; Latocha et al., 2010; Hunter et al., 2011). In the last decade many authors have reported their results of successful introduction and adaptation of Actinidia genus plants in Ukraine (Skriptchenko, 2001), Poland (Marosz, 2009; Bieniek, 2012) and Lithuania (Česonienè et al., 2010]. In Moldova there are no orchards of Actinidia, but during last eight years at the Experimental station of the Institute of Genetics \& Plant Physiology of the Academy of Science of Moldova (IGPP, ASM) Actinidia arguta is propagated and investigated. The first goal of this research was to elaborate the methods of multiplication in vitro, followed by plant adaptation to ex vitro conditions. The second goal was to evaluate the total phenolic content and antioxidant activity of Actinidia arguta fruits, harvested from our experimental station, during storage.

\section{MATERIALS AND METHODS}

\section{Plant material}

Primarily, Actinidia arguta plants were obtained from seeds. Genotypes characterized by rapid growth and strong root systems were evaluated and finally a vigorous and highly productive Tatiana clone was selected (Fig. 1). In environmental conditions of IGPP experimental station (lat. $47^{\circ} 01^{\prime}$, long. $28^{\circ} 52^{\prime}$, alt. $173 \mathrm{~m}$ above sea level) Actinidia arguta buds appear in May and remain closely associated with sepals until early June. It is noteworthy that during this period late spring frosts are excluded and there is no danger for plants to be damaged by frost. The flowers, mostly hidden in foliage, persist for several weeks. Flowers of male exemplars are assembled in inflorescence with numerous flowers (Fig. 2a), but female plants are separated or aggregated in clusters with 2-3 flowers (Fig. 2b). The leaves are long (up to $15 \mathrm{~cm}$ ), oval with rounded apexes. Their dark green colour keeps almost unchanged throughout the growing season, only in fall the leaves turn yellow (Fig. 3). The apical shoots from adult plants were used for elaborating the method of in vitro micropropagation. They were sterilized by immersing during $15 \mathrm{~min}$

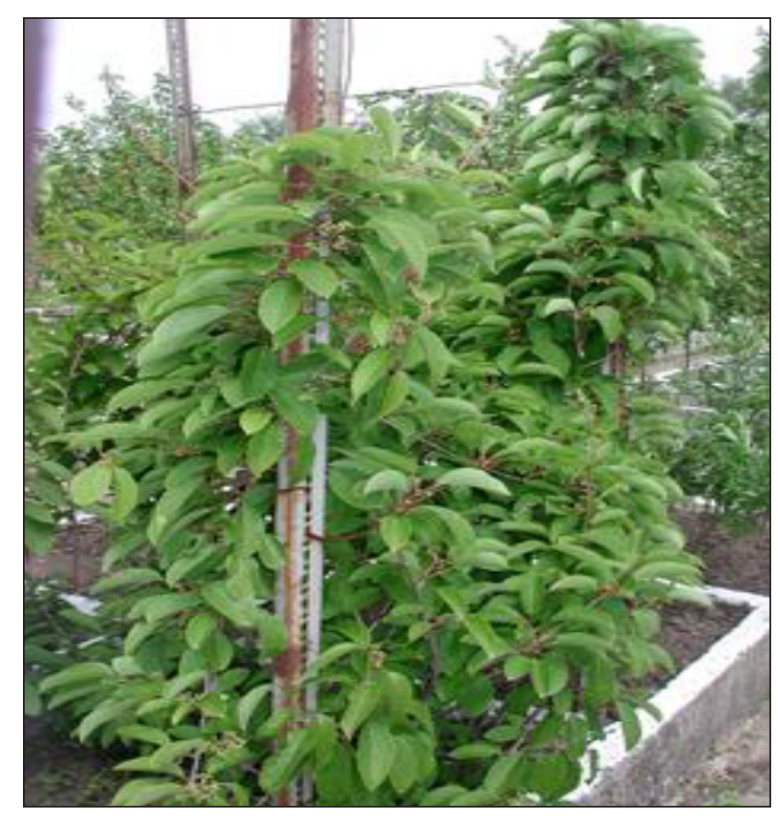

Fig. 1. Tatiana clone of Actinida arguta 

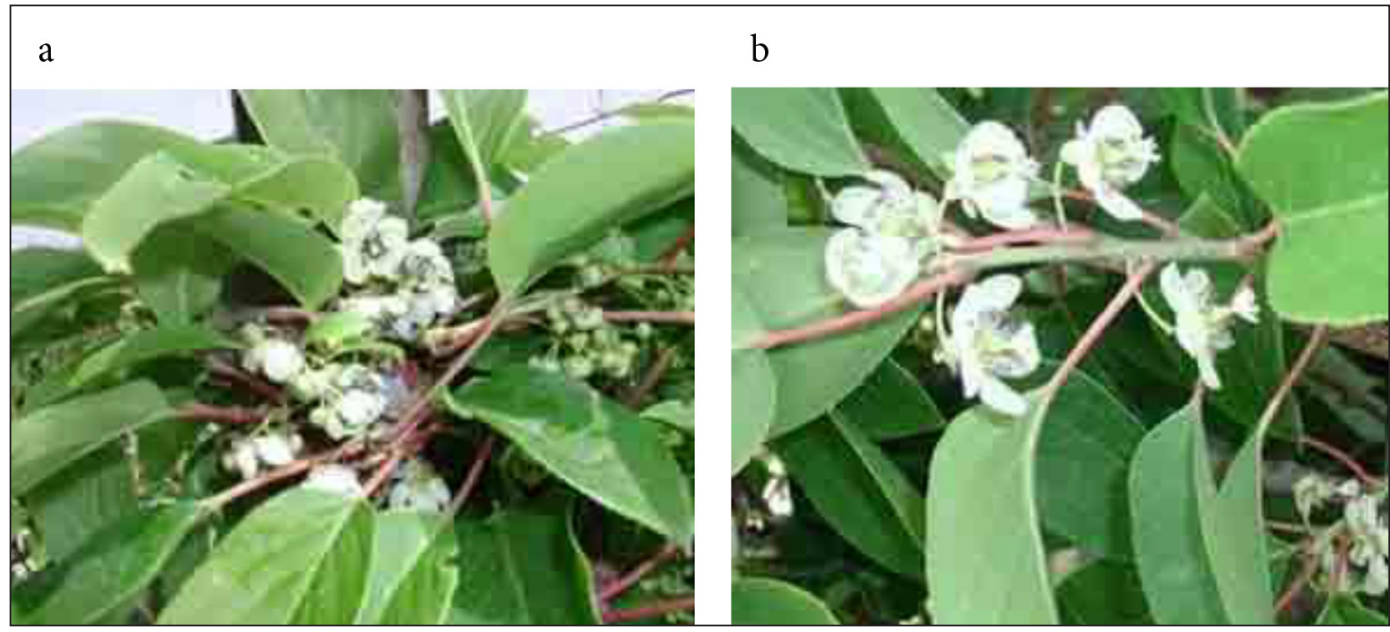

Fig. 2. Male (a) and female (b) plants of Actinidia arguta (Tatiana clone)

in solution containing chlorine (20\% ACE), followed by washing with sterile water.

\section{Plant multiplication and cultivation}

The medium based on classical mineral salt composition (Murashige et al., 1962) was used for shoots cultivation in vitro. Explants were grown at temperature $26{ }^{\circ} \mathrm{C}$ under light (1 000 lux) with photoperiod about $16 \mathrm{hrs}$ at light and 8 hrs in darkness. Plants adaptation to ex vitro conditions was assured by increasing gradually the light intensity from 1000 lux up to $7000-9000$ lux and reducing the

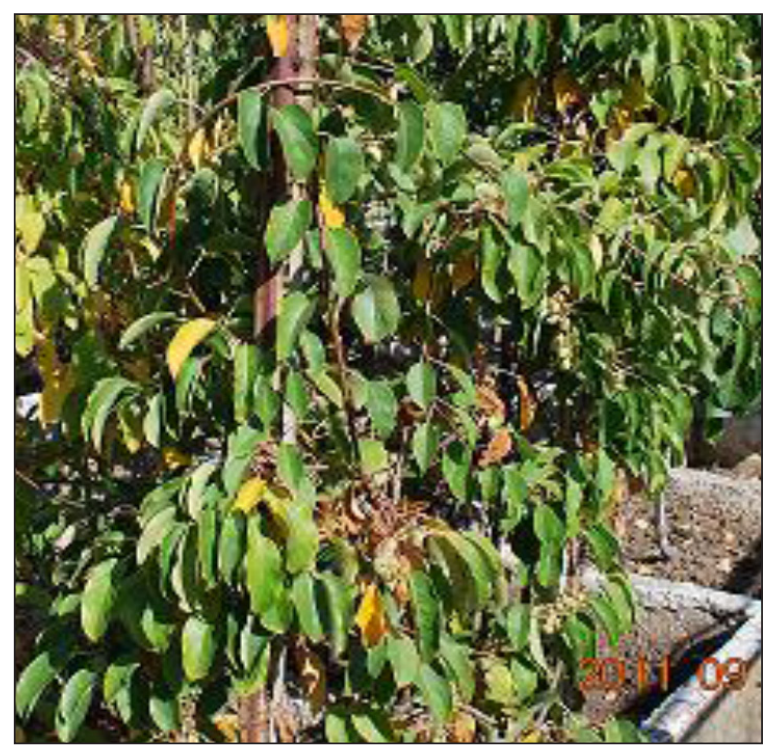

Fig. 3. Fall image of Actinidia arguta (Tatiana clone) relative humidity from $95 \%$ to natural. After adaptation to ex vitro conditions, during the first year, plants were grown in the nursery and then transferred to a constant location, maintaining the relationship between feminine and masculine plants 5:1.

\section{Characteristics of the Tatiana clone fruits}

Ovate or oblong hardy kiwifruits (Fig. 4) were collected from mature plants of Tatiana clone (5-6 years old). The crop yield from one 5-7year plant of Tatiana clone was varying between 2 and $10 \mathrm{~kg}$. Fruits were $2-3 \mathrm{~cm}$ in length

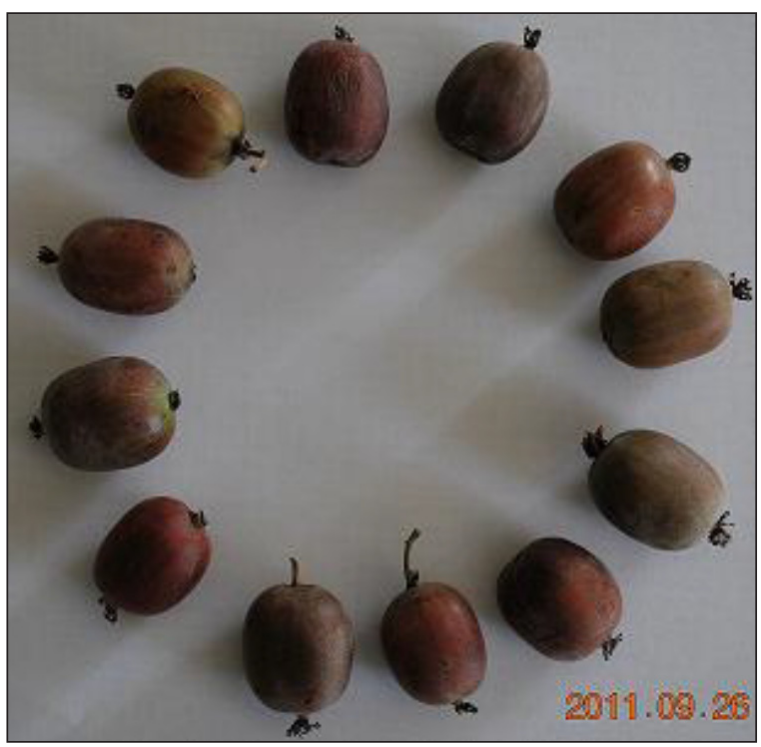

Fig. 4. Hardy kiwifruits of Tatiana clone 
and weighed $4.5 \mathrm{~g}$, depending on conditions and load of plants with fruits. The fruits were considered ripe when they became brownviolet and the content of soluble sugars reached $6-7 \%$. Collection of fruits at the brown-green stage is also possible, due to their capacity of after-ripening during storage at temperatures above $4{ }^{\circ} \mathrm{C}$. In conditions of our experimental station the fruits of Tatiana clone ripen in September and October. For determining their biochemical characteristics, the ripened fruits were frozen and until analysis were stored at -18 C. Ordinarily, the antioxidant activity and phenolic content was provided in kiwifruits juice obtained by direct press operation using Hydraulic Plant Sap Press (Spectrum Technologies Inc., USA).

\section{Determination of total phenolic content}

The total phenolic content of juice was assessed by using the Folin-Ciocalteu phenol reagent method (Singleton et al., 1999). To $0.1 \mathrm{ml}$ of the cell sap, previously diluted 1:2.5 ( $\mathrm{vol} / \mathrm{vol})$ with distilled water, $2.3 \mathrm{ml}$ of distilled water and $0.2 \mathrm{ml}$ Folin-Ciocalteu reagent were added. The mixture was kept at room temperature for 3-5 min and after that $1.4 \mathrm{ml}$ of sodium carbonate ( $29 \% \mathrm{wt} / \mathrm{vol})$ was added, vigorously $\mathrm{mi}$ xed, and before measuring the absorbance on a spectrophotometer UV/VIS (Agilent 8453) at $760 \mathrm{~nm}$ were incubated for $40 \mathrm{~min}$ at $18-20^{\circ} \mathrm{C}$. A mixture of water and reagents was used as a blank. The total phenolic content was expressed as gallic acid equivalents (GAE) in g/l of juice. Each sample was measured in triplicate.

\section{Evaluation of antioxidant activity}

Antioxidant activity was evaluated by measuring peroxyl radical scavenging activity (RSA). The assay is based on the degree of inhibition of potassium iodide oxidation by antioxidants that scavenge peroxyl radicals generated from thermal degradation of 2,2'-azobis(2-amidinopropane)-dihydrochloride (Sano et al., 2003; Ivanova, 2007). The amount of iodine, released during the oxidation, was determined by potentiomet- ric titration using the automatic titrator "Titroline easy" (Germany) with minimum titration amount of sodium thiosulfate $0.1 \mathrm{ml}$. RSA of tested juice was expressed as the inhibition ratio for iodine release in comparison with control sample (without juice). The reproducibility of RSA assay is good. The coefficients of variance are less than $4.78 \%$ and mean relative errors are within $\pm 7.01 \%$. The linear relationship between RSA and concentration of standard antioxidant (gallic, elagic, chlorogenic, ascorbic acids and rutine) had high Pearson's correlation coefficients $\left(\mathrm{r}^{2}=0.848-0.997\right)$ (Ivanova et al., 2004). Antioxidant potential of kiwifruits juice was compared with equivalent activity of ascorbic acid pure substance and calculated in the vitamin $\mathrm{C}$ equivalent antioxidant capacity (VCEAC).

\section{RESULTS AND DISCUSSION}

\section{Multiplication in vitro}

For in vitro propagation of clone Tatiana plants different cultivation mediums were tested. The best results were obtained with modified Murashige-Stoog methods. The comparative results are included in Table.

As a result, the optimal cultural medium and conditions of cultivation, allowing the propagation of plants with the multiplication factor equal to seven, were determined (Fig. 5).

\section{Antioxidant activity}

During the biochemical analysis we evaluated that $100 \mathrm{~g}$ of fresh kiwifruits contain $85.50 \pm 0.45 \mathrm{mg}$ of ascorbic acid; $127.64 \pm$ $6.09 \mathrm{mg}$ of total phenolics, including $7.30 \pm$ $0.36 \mathrm{mg}$ of flavonols and $1.80 \pm 0.09 \mathrm{mg}$ of oxycinnamic acids. Antioxidant activity of kiwifruits was compared with the same index of edible fruits and berries growing in Moldova (Fig. 6). VCEAC of kiwifruits was equal to $9.26 \pm 0.28 \mu \mathrm{Mol} / \mathrm{g}$ (per dry residue) that was higher than antioxidant capacities of apricot and Moldova grape, but significantly lower than those of strawberries and red currant. Our results are supported by the data of other 
Table. The results of Tatiana clone plants propagation in vitro obtained by utilizing the classical MurashigeSkoog medium and its two modifications

\begin{tabular}{c|c|c|c}
\hline \multirow{2}{*}{ Index } & \multicolumn{3}{|c}{ Method } \\
\cline { 2 - 4 } $\begin{array}{c}\text { Reagent content in } \\
\text { cultivation medium }\end{array}$ & $\begin{array}{c}\text { Classical } \\
\text { Murashige-Skoog } \\
\text { (Murashige et al., } \\
\text { 1962) }\end{array}$ & $\begin{array}{c}\text { Classical Murashige- } \\
\text { Skoog + 6-benzil- } \\
\text { aminopurin } \\
\text { (Vysotskii et al., 1991) }\end{array}$ & $\begin{array}{c}\text { II/2 from classical Murashige- } \\
\text { Skoog + activated carbon } \\
\text { (Calugaru-Spataru et al., } \\
\text { 2013) }\end{array}$ \\
\hline $\begin{array}{c}\mathrm{pH} \text { medium after } \\
\text { sterilization }\end{array}$ & 5.8 & 5.8 \\
\hline \multicolumn{4}{|c}{ Growing dynamics, days } \\
\hline Growing start & $16-19$ & $12-15$ & $7-10$ \\
\hline 1.5-2.0 cm & $38-42$ & $28-30$ & $15-20$ \\
\hline 3-5 cm & $48-54$ & $38-42$ & $28-30$ \\
\hline Full cycle, weeks & $18-19$ & $14-16$ & $10-12$ \\
\hline Cycles for the year & 3 & 3.5 & 7.5 \\
\hline $\begin{array}{c}\text { Coefficient of } \\
\text { propagation }\end{array}$ & 5.2 & 6.4 \\
\hline
\end{tabular}

researchers utilizing other procedures of antioxidant activity determination (Scalzo et al., 2005).

During the storage of frozen fruits a decrease of the content of phenolic compounds and antioxidant activity of fruit juice was observed (Fig. 7). The major drop of phenolic compounds content occurred in the first six weeks of storage (23\%). Later their content decreased very slowly during one year of storage (from $23 \%$ to $29 \%$ ). This implies that some individual components degrade more quickly than others. On the contrary, during the first months of storage the index of antioxidant activity of fruit juice remained practically unchanged, while starting from 4-5 months of storage its value decreased very rapidly. During one year storage the values of this index were decreased by approximately $40 \%$. Given the fact that in this period the reduction of phenolic compounds in juice of hardy kiwifruits was insignificant, it can be assumed that the reduction of radical scavenging activity was mainly because of ascorbic acid oxidation. It is known that the content of ascorbic acid in fruits decreases during long-term storage. Also, there is some information that the carotenoid and phenolic components in Actinidia fruits are more resistant to light, low temperature and storage time than ascorbic acid (Gil et al., 2006). Our

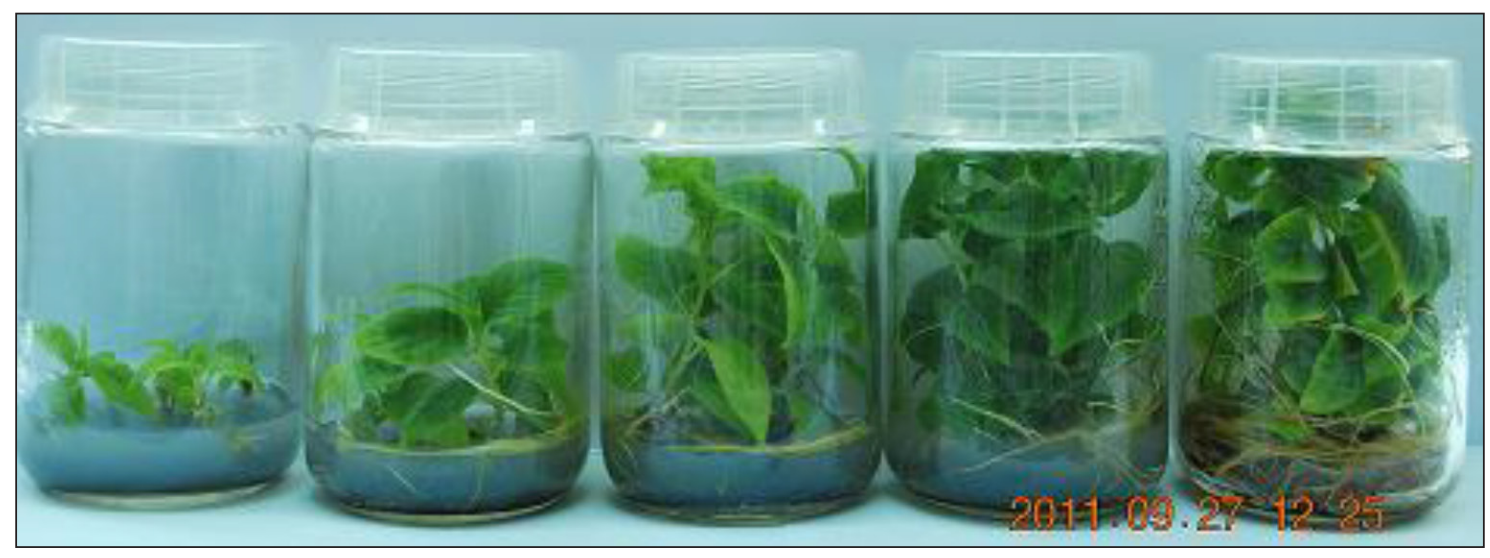

Fig. 5. Dynamics of Actinidia arguta in vitro growing 


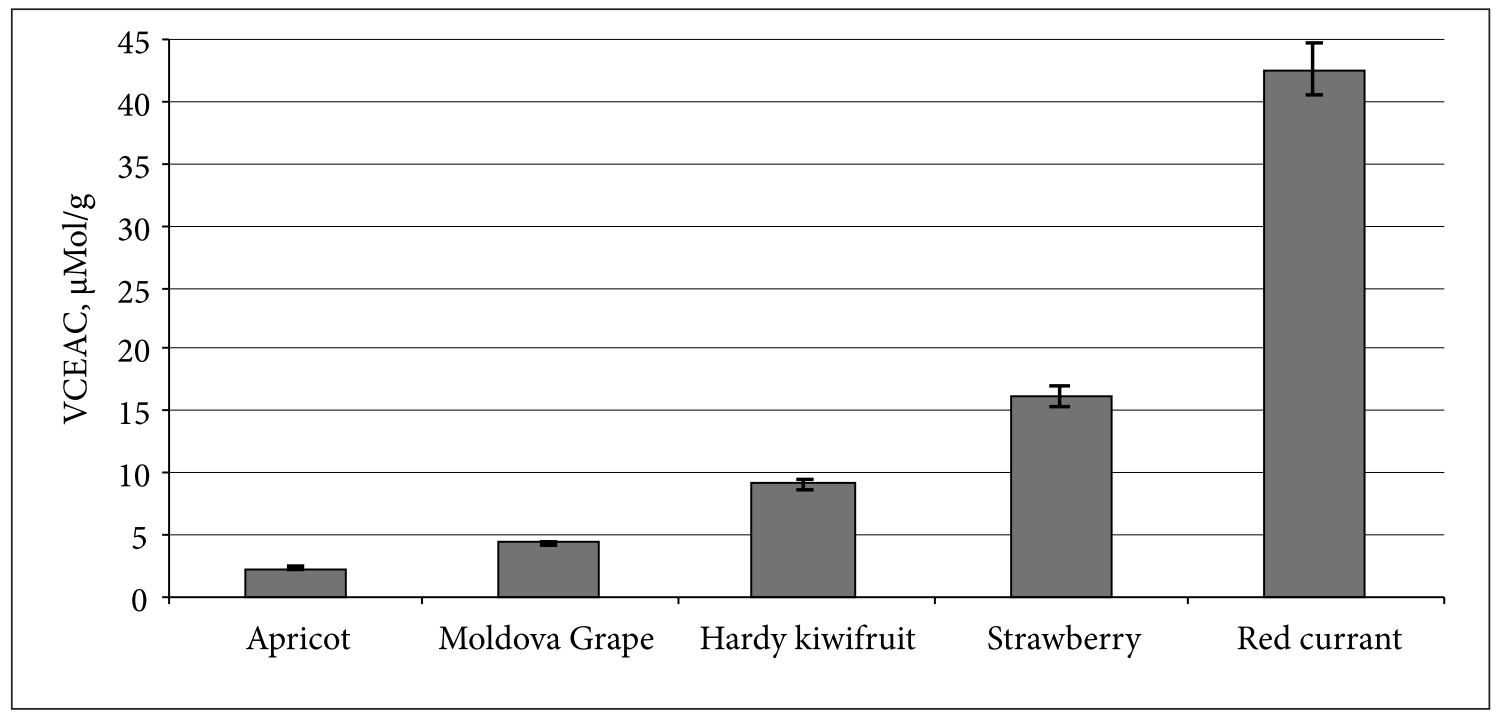

Fig. 6. Antioxidant activity (VCEAC) of edible fruits and berries growing in Moldova

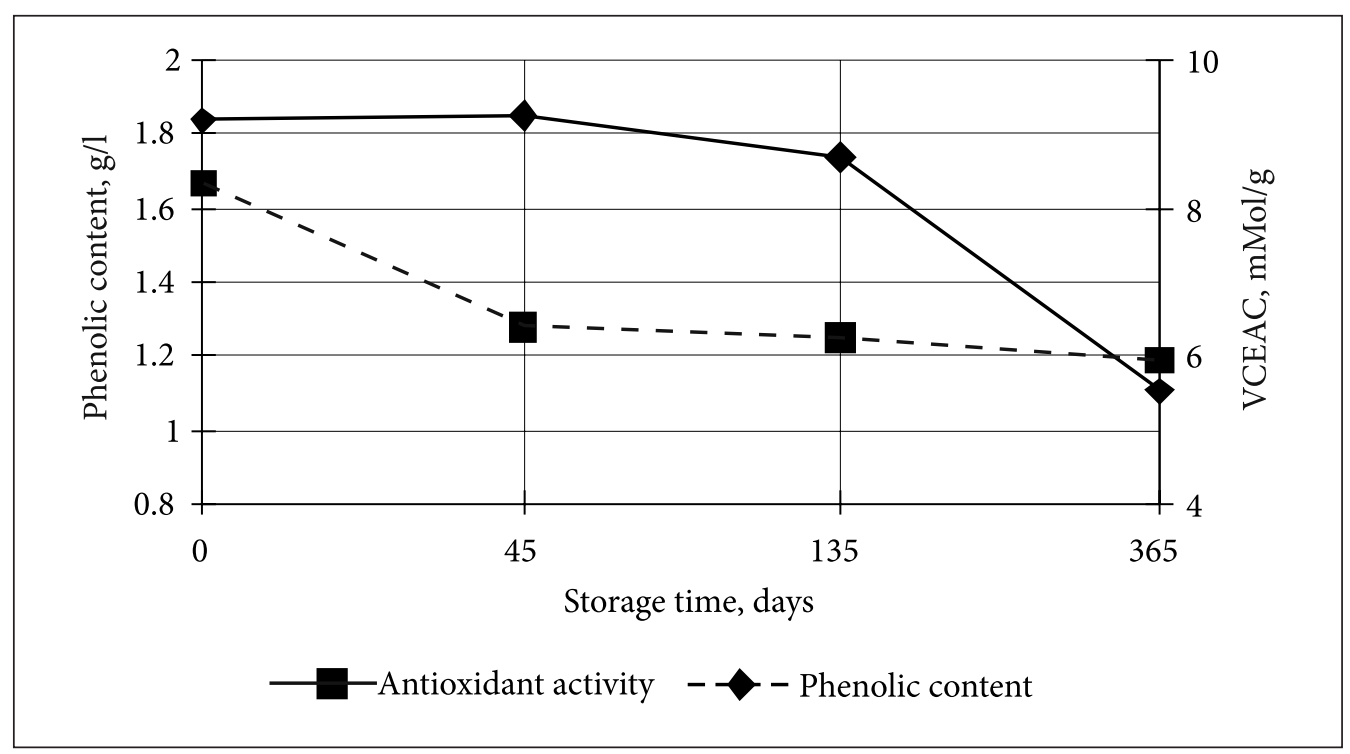

Fig. 7. Changes in phenolic content and antioxidant activity (VCEAC) of hardy kiwifruits juice during storage

data show that approximately $71 \%$ of phenolic compounds are stable in frozen fruits during one year of their storage.

\section{CONCLUSIONS}

1. Tatiana is a valuable genotype clone of Actinidia arguta which can be recommended for cultivation in Moldova ensuring artificial watering during drought.
2. The developed methods of in vitro micropropagation and cultivation support the idea about the possibility of achieving highly productive plantations of Actinidia arguta in a short time.

3. The hardy kiwifruits of Tatiana clone contain biochemical substances with the significant antioxidant potential and nutritional value which are preserved during one year storage of frozen fruits. 


\section{ACKNOWLEDGEMENTS}

The authors thank PhD Igor Casian from the Scientific Centre Field of Medicines, "Nicolae Testemitanu" State University of Medicine and Pharmacy (Chisinau, Moldova) for the assistance in content determining of flavonols and oxycinnamic acids in fresh kiwifruits.

Received 18 May 2013 Accepted 24 August 2013

\section{References}

1. Zuo LL, Wang ZY, Fan ZL, Tian SQ, Liu JR. Evaluation of antioxidant and antiproliferative properties of three Actinidia (Actinidia kolomikta, Actinidia arguta, Actinidia chinensis) extracts in vitro. Int J Mol Sci 2012; 13: 5506-18.

2. Marosz A. Comparison of winter hardiness and growth of Actinidia arguta and A. kolomikta cultivars grown in central Poland. Acta Agrobot 2009; 62(2): 179-85.

3. Nishiyama I, Yamashita Y, Yamanaka M, Shimohashi A, Fukuda T, Oota T. Varietal difference in vitamin $\mathrm{C}$ content in the fruit of kiwifruit and other Actinidia species. J Agr Food Chem 2004 Aug 25; 52(17): 5472-5.

4. Nishiyama I, Fukuda T, Oota T. Genotypic differences in chlorophyll, lutein, and betacarotene contents in the fruits of Actinidia species. J Agr Food Chem 2005 Aug 10; 53(16): 6403-7.

5. Motohashi N, Shirataki Y, Kawase M, Tani S, Sakagami H, Satoh K, Kurihara T, Nakashima H, Wolfard K, Miskolci C, Molnár J. Biological activity of kiwifruit peel extracts. Phytother Res 2001 Jun; 15(4): 337-43.

6. Scalzo J, Politi A, Pellegrini N, Mezzetti B, Battino M. Plant genotype affects total antioxidant capacity and phenolic contents in fruit. Nutrition 2005 Feb; 21(2): 207-13.

7. Ivanova R, Dascaliuc A. In vitro study of antioxidant capacity of Actinidia fruits growing in
Moldova. Amb Medium 2010; 4(52): 29-31 (in Russian).

8. Latocha P, Krupa T, Wołosiak R, Worobiej E, Wilczak J. Antioxidant activity and chemical difference in fruit of different Actinidia sp. Int J Food Sci Nutr 2010; 61(4): 381-94.

9. Hunter DC, Greenwood J, Zhang J, Skinner MA. Antioxidant and 'natural protective' properties of kiwifruit. Curr Top Med Chem 2011; 11(14): 1811-20.

10. Skriptchenko N. State and perspectives of Actinidia culture development in Ukraine. Proceedings of 9th International conference of horticulture, Sep 13-15, 2001; Lednice, Czech Republic, 2001; 1: 219-23.

11. Bieniek A. Yield, morphology and biological value of fruits of Actinidia arguta and Actinidia purpurea and some of their hybrid cultivars grown in north-eastern Poland. Acta Sci Pol Hortorum Cultus 2012; 11(3): 117-30.

12. Česonienè L, Daubaras R. Investigation of Actinidia genus genetic resources at Kaunas Botanical Garden of Vytautas Magnus University. Vytauto Didžiojo universiteto Botanikos sodo raštai 2010; 14: 48-54.

13. Murashige T, Skoog F. A revised medium for rapid growth and bio-assays with tobacco tissue cultures. Physiol Plantar 1962; 15(95): 473-9.

14. Singleton VL, Orthofer R, Lamuela-Raventos RM. Analysis of total phenolics and other oxidation substrates and antioxidants by means of Folin-Ciocalteu reagent. Lester Packer (ed.). Methods in Enzymology. V. 299. Oxidants and Antioxidants. Part A; 1999, 15278.

15. Sano M, Yoshida R, Degawa M, Miyase M, Yoshino K. Determination of peroxyl radical scavenging activity of flavonoids and plant extracts using an automatic potentiometric titrator. J Agr Food Chem 2003; 51(10): 2912-16.

16. Ivanova RA. The potentiometric assay for measurement of peroxyl radical scavenging capacity of plant extracts. Herba polonica 2007; 53(2): 136-7. 
17. Ivanova RA, Prida AI. Study of radical scavenging properties of dry extracts of polyphenol containing raw materials. Proceedings of 8th International Congress "Actual problems of creation of new medicinal preparations of natural origin"; June 21-23, 2004, Mikkeli, Finland, 2004, 431-4 (in Russian).

18. Vysotskii VA, Barteneva LB. Features of Actinidia clonal micropropagation. Moscow Science (ed.). Biology of cultivated cells and plants biotechnology. 1991; 213-6 (in Russian).

19. Calugaru-Spataru T, Dascaliuc A. Inventor: Institute of Genetics and Plant Physiology, Academy of Science of Moldova. Process of in vitro micropropagation of Actinidia arguta plants. Republic of Moldova Patent 605, March 2013 (in Romanian).

20. Gil MI, Aguayo E, Kader AA. Quality changes and nutrient retention in fresh-cut versus whole fruits during storage. J Agr Food Chem 2006 Jun 14; 54(12): 4284-96.

\section{Tatiana Calugaru-Spataru, Raisa Ivanova, Alexandru Dascaliuc \\ ACTINIDIA ARGUTA DAUGINIMAS IR AUGINIMAS IN VITRO MOLDOVOS RESPUBLIKOJE}

\section{Santrauka}

Actinidia arguta yra vaisius vedantis vynmedis, nebūdingas natūraliai Moldovos augmenijai. Dèl aukštos dekoratyvinès vertės ir egzotinių vaisių ši rūšis labai domina sodininkus. Moldovos mokslų akademijos Genetikos ir augalu fiziologijos instituto Bandomajame sektoriuje ši rǔšis tyrinèta aštuonerius metus. Ypatingas dèmesys buvo skirtas aukšto produktyvumo klono 'Tatiana', pasirinkto iš anksčiau atliktų vegetatyvinių dauginimų, auginimo sąlygoms ir vegetatyvinio dauginimo metodams tobulinti. Šių suaugusių augalų viršūninès meristemos buvo naudojamos kaip tyrimų in vitro medžiaga. Augalo dauginimas in vitro (kai dauginimo veiksnys lygus 7) ir organogenezė buvo detalizuota išbandant skirtingas maistines medžiagas. Augalų adaptacija ex vitro sąlygomis buvo patikrinta palaipsniui didinant šviesos intensyvumą ir mažinant santykini oro drègnumą nuo $95 \%$ link natūralaus. Vidurio Moldovos sąlygomis vieno 'Tatiana' klono derlius 5-7 metų laikotarpiu svyravo tarp 2 ir 10 kilogramų. Buvo įvertintos vaisių biologinès ir juslinès savybès. Vaisių sulčiu antioksidacinis aktyvumas buvo nustatytas potenciometriniais metodais; vitamino $\mathrm{C}$ kiekis buvo 9,26 $\pm 0,28 \mu \mathrm{Mol} / \mathrm{g}$ (sausojoje dalyje). Dèl didelio fenolinių junginių kiekio 'Tatiana’ klonų vaisiai išlieka stabilūs visą laikymo laikotarpị ir gali tapti vertingu maistingos medžiagos šaltiniu.

Raktažodžiai: Actinidia arguta, mikrodauginimas in vitro, antioksidacinis aktyvumas, fenoliai 